\title{
33 \\ MATTERS RESERVED FOR THE BOARD
}

David Doughty

Key to the board's effectiveness is the relationship between the board and senior management - the foundation of this relationship is a clear understanding of where the board's duties and responsibilities end, and the management's duties and responsibilities begin.

It is vital for this understanding that this delineation is written down in a document which is either referred to as "Matters Reserved for the Board" or "Delegation of Authority." It is a requirement of the UK Corporate Governance Code $^{1}$ that "The responsibilities of the chair, chief executive, senior independent director, board and committees should be clear, set out in writing, agreed by the board and made publicly available."

In the unitary board, executive directors wear two hats - they are part of the board team providing direction for the company and they are also the senior managers tasked by the board to deliver its objectives. This

1 UK Corporate Governance Code: Frc.org.uk. 2017. UK Corporate Governance Code. [online] Available at: www.frc.org.uk/Our-Work/Codes-Standards/Corporategovernance/UK-Corporate-Governance-Code.aspx.

DOI: $10.4324 / 9781003201182-39$ 
dichotomy can only be resolved by having the utmost clarity as to what is required of them in each role.

With two-tier boards such as the German management and the supervisory board system, board members are usually not allowed to belong to both boards. In general, the management board has the power to manage and represent the company independently, and the supervisory board has the function to supervise and advise the management board.

The unitary, one-tier board structure is found in Australia, Canada, Hong Kong, India, Ireland, Japan, Macau, Malta, Puerto Rico, Russia, Singapore, South Africa, South Korea, Spain, Switzerland, Trinidad and Tobago, Turkey, the UK, and the USA, whilst the two-tier board structure is common in China, Belgium, Germany, and Indonesia. Both one- and two-tier systems can be found in France, Italy, Luxembourg, Mexico, and the United Arab Emirates

Generally, in the countries above, listed companies are subject to corporate governance codes, similar to the UK Corporate Governance Code or legislation, similar to the US Dodd-Frank ${ }^{2}$ and Sarbanes-Oxley ${ }^{3}$ Acts. Nonlisted companies, though not required to by law, tend to follow the spirit of the prevailing legislation for listed companies as it is seen to be best practice.

\section{Board checklist}

Tick the box, where appropriate, for who has responsibility for the following matters:

\section{Questions to ask}

- Does the board clearly delegate authority to management?

- Is there a clear division of responsibilities between the leadership of the board and the executive leadership of the company's business?

- Is there a formal schedule of matters specifically reserved for the board's decision?

2 Dodd Frank Act: Wall Street Reform and Consumer Protection Act, Pub. L. No. 111-203, § 929-Z, 124 Stat.

3 Sarbanes Oxley Act: Soxlaw.com. 2015. Sarbanes-Oxley Act Summary and Introduction. [online] Available at: www.soxlaw.com/introduction.htm. 
Table 33.1 Board responsibilities for the unitary board

\begin{tabular}{|c|c|c|c|}
\hline The Unitary (1-Tier) Board & Shareholders & Board of Directors & Executive Board \\
\hline \multicolumn{4}{|l|}{ Strategy and management } \\
\hline \multicolumn{4}{|l|}{ Structure } \\
\hline \multicolumn{4}{|l|}{ Financial reporting and controls } \\
\hline \multicolumn{4}{|l|}{ Internal controls } \\
\hline \multicolumn{4}{|l|}{ Contracts } \\
\hline \multicolumn{4}{|l|}{ Communication } \\
\hline \multicolumn{4}{|l|}{ Conflicts of interest } \\
\hline \multicolumn{4}{|l|}{ Board membership and other appointments } \\
\hline \multicolumn{4}{|l|}{ Remuneration } \\
\hline \multicolumn{4}{|l|}{ Delegation of authority } \\
\hline \multicolumn{4}{|l|}{ Corporate governance matters } \\
\hline \multicolumn{4}{|l|}{ Policies } \\
\hline Other & & & \\
\hline
\end{tabular}

Table 33.2 Board responsibilities for the two-tier board

The 2-Tier Board Shareholders Supervisory Board Management Board

Strategy and management

Structure

Financial reporting and controls

Internal controls

Contracts

Communication

Conflicts of interest

Board membership and other appointments

Remuneration

Delegation of authority

Corporate governance matters

Policies

Other

- Is it clear that the board is responsible for formally approving interim and final dividends, interim and annual reports, accounts, and communications to shareholders?

- Does the board formally take responsibility for establishing and maintaining the company's purpose, vision, mission and values, and strategy? 
- Does the board set a financial threshold above which the chief executive has to obtain board approval for loan capital, capital expenditure, acquisitions, joint ventures, and disposals?

- Is there a clear policy in place with regard to the board's authority to appointment or remove the chief executive, other executive directors, and the company secretary?

- Are board members aware of what is expected of them in terms of their fiduciary duties and legal responsibilities?

- Is there is a clear understanding of where the board's role ends and the senior management team's begins?

- Is there good two-way communication between the board and the senior management team?

- Does the board trust the judgement of the senior management team?

- Has the board discussed and communicated the kinds of information and level of detail it requires from the senior management team?

- Are there clear terms of reference for the board, the directors, and the managers?

- Does the board own the strategic risk register?

- Does the board regularly undertake reviews of its own performance, that of its committees, and individual board members?

- Does the board ensure that the chair conducts a formal annual appraisal of the chief executive?

- Is the board responsible for approval of the overall levels of insurance for the company including directors' and officers' liability insurance?

- Does the board have clear responsibility for major changes to the rules of the company's pension scheme?

- Does the company's annual report contain a high-level statement of which types of decisions are to be taken by the board and which are to be delegated to management?

- Does the board have the authority to obtain outside legal or other independent advice at the expense of the company?

- Is the board clearly responsible for the adoption of significant changes in accounting policies or practices?

- Does the board's "Matters Reserved for the Board" statement include the recommendation to shareholders for approval alterations to the memorandum and articles of association of the company? 
- Is it clear that the board is responsible for making any take-over offer for another company or other companies, and considering a response to any such approaches to the company?

- Is the board responsible for reviewing succession plans for the board and senior management of the company?

- Is the chief executive required to obtain board approval of all significant changes to the company's activities including acquisitions or divestments, or entry into a new foreign jurisdiction, or exit from an existing one?

- Is it clearly understood by senior management that the board must be advised of all material litigation either proposed by or commenced against the company, including recommendations for settlement or an alternative dispute mechanism?

- Is the board responsible for recommending to shareholders the appointment or removal of the company's auditors including approval of their fees?

- Is it clear that the board is responsible for considering the balance of interests between shareholders, employees, customers, and the community? 